Jurnal Keperawatan Silampari

Volume 4, Nomor 1, Desember 2020

e-ISSN: 2581-1975

p-ISSN: 2597-7482

DOI: https://doi.org/10.31539/jks.v4i1.1715

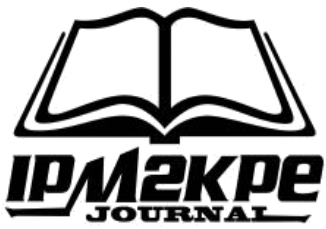

\title{
PELATIHAN BALUT BIDAI TERHADAP KETERAMPILAN PADA MAHASISWA/I KEPERAWATAN
}

\author{
Devi Listiana ${ }^{1}$, Yulita Elvira Silviani ${ }^{2}$ \\ Sekolah Tinggi Ilmu Kesehatan Tri Mandiri Sakti Bengkulu ${ }^{1,2}$ \\ devilistiana01@gmail.com ${ }^{1}$
}

\begin{abstract}
ABSTRAK
Tujuan penelitian ini adalah untuk mengetahui pengaruh pelatihan balut bidai terhadap keterampilan pada mahasiswa/i keperawatan di STIKES Tri Mandiri Sakti Bengkulu. Metode penelitian yang digunakan dalam penelitian ini adalah pre-eksperimental dengan rancangan one group pre-test post-test design. Hasil penelitian ini menunjukkan bahwa keterampilan sebelum perlakuan dan sesudah perlakukan sebesar -9,247 dengan nilai $\mathrm{p}=0,000$ ( $\mathrm{p}$-value $<0,05$ ). Simpulan, ada pengaruh pelatihan balut bidai terhadap keterampilan pada mahasiswa/i keperawatan di STIKES Tri Mandiri Sakti Bengkulu.
\end{abstract}

Kata Kunci: Keterampilan, Pelatihan Balut Bidai

\section{ABSTRACT}

This study aimed to determine the effect of splint dressing training on the skills of nursing students at STIKES Tri Mandiri Sakti Bengkulu. The research method used in this study was pre-experimental with one group pre-test post-test design. The results of this study indicate that the skills before treatment and after treatment are -9.247 with a value of $p=0.000$ ( $p$-value <0.05). In conclusion, there is an effect of splint dressing training on nursing students' skills at STIKES Tri Mandiri Sakti Bengkulu.

Keywords: Skills, Bidai Dressing Training

\section{PENDAHULUAN}

Sudah menjadi tanggung jawab petugas kesehatan untuk menangani masalah kondisi kegawatdaruratan yang dapat terjadi dimana saja dan kapan saja. Tidak menutup kemungkinan kondisi kegawatdaruratan dapat terjadi pada daerah yang sulit dijangkau oleh petugas kesehatan. Peran serta masyarakat dan mahasiswa untuk membantu korban sebelum ditangani oleh petugas kesehatan menjadi sangat penting pada kondisi tersebut (Warouw et al., 2018).

Bencana adalah kejadian yang mengakibatkan kerusakan, gangguan ekologis, hilangnya nyawa manusia, dan memburuknya derajat atau pelayanan kesehatan pada skala tertentu yang memerlukan respon dari masyarakat wilayah yang terkena bencana (Najihah \& Ramli, 2019). Di dekade terakhir, jumlah total peristiwa bencana hampir dua kali lipat, menunjukkan garis trend dari sekitar 450 hingga 800 darurat besar pertahun. Peningkatan ini paling ditandai di negara berpenghasilan menengah dan rendah, di mana kesiapsiagaan darurat sering tidak mencukupi. Karena peningkatan kesiapsiagaan di banyak negara, lebih sedikit orang meninggal karena peristiwa bencana, tetapi jumlah orang yang terkena dampaknya masih meningkat, dengan jangka 
panjang yang penting implikasi.

WHO akan bermitra dengan PBB Internasional Strategi untuk Pengurangan Bencana (ISDR) dan badan-badan PBB dan non-PBB lainnya pada 2008-2009 Safe Hospitals Initiative, yang bertujuan membangun ketahanan rumah sakit dan kesehatan lainnya fasilitas untuk bencana, baik struktural dan fungsional, sehingga mereka akan tetap berfungsi di bawah situasi darurat. Bukan hanya bencana alam yang terjadi, berdasarkan data WHO 2018 diperkirakan 70\% kecelakaan lalu lintas di alami oleh pelajar/mahasiswa. Organisasi kesehatan dunia WHO mencatat 1,2 juta orang meninggal setiap tahunnya dalam kecelakaan lalu lintas dan 50 juta orang korban kecelakaan lalu lintas mengalami luka serius maupun cacat tetap (Sumadi, 2020).

World Health Organization (WHO) mengemukakan bahwa kecelakaan lalu lintas merupakan penyebab kematian nomor 8 dan merupakan penyebab kematian teratas pada penduduk usia 15 - 29 tahun di dunia dan jika tidak ditangani dengan serius pada tahun 2030 kecelakaan lalu lintas akan meningkat menjadi penyebab kematian kelima di dunia. Pada tahun 2011- 2012 terdapat 5,6 juta orang meninggal dunia dan 1,3 juta orang menderita fraktur akibat kecelakaan lalu lintas (Desiartama \& aryana, 2017; Andri et al., 2020).

Salah satu studi di Vancouver, British Colombia (Kanada) tingkat kecelakaan yang terjadi di lingkungan sekolah sebesar 1,8 per 100 anak. Penelitian tersebut melaporkan tingkat cedera kepala sebesar 1,8 per 100 anak, cedera yang meliputi perdarahan, terkilir, fraktur (patah tulang) dan gagar otak sebesar 0,09 per 100 anak. Sementara itu studi lain menyebutkan bahwa luka yang diderita oleh mahasiswa adalah $26,4 \%$ berada di jalan, 23,1\% terjadi di sekolah, 28,6\% aktivitas olahraga dan $22 \%$ terjadi di rumah (Warouw et al., 2018).

Berdasarkan data 3 tahun terakhir di Bengkulu untuk kejadian bencana pada tahun 2017 sering terjadi tanah longsor dengan jumlah kejadian 7 kali, puting beliung dengan jumlah kejadian 5 kali, banjir dengan jumlah kejadian 5 kali, dan gempa bumi dengan kejadian 1 kali. Pada tahun 2018 data bencana yang sering terjadi di Bengkulu banjir dengan jumlah kejadian 5 kali, gempa bumi dengan jumlah kejadian 2 kali, tanah longsor dengan jumlah kejadian 1 kali. Sedangkan pada tahun 2019 ini sering terjadi banjir di Provinsi Rejang Lebong jumlah kejadian 3 kali dan tanah longsor yang terjadi di Seluma dan Kepahiang dengan jumlah kejadian 1 kali. Bengkulu wilayah rawan gempa bumi dan tsunami karena wilayah Bengkulu terletak pada pertemuan lempeng tektonik Indo-Australia dan Eurasia yang merupakan generator utama aktivitas gempa bumi dan garis pantai dengan panjang lebih kurang $512 \mathrm{Km}$. Bengkulu wilayah rawan longsor karena berhadapan dengan bukit barisan dengan tingkat kelerengan di atas 60 derajat. Bengkulu wilayah rawan banjir karena panjang sungai di Bengkulu rata-rata 86 km dengan hulu sungai berada pada kawasan bukit barisan (Listiana et al., 2019).

Kejadian bencana yang pernah terjadi di STIKES Tri Mandiri Sakti Bengkulu adalah gempa bumi yang membuat beberapa orang cedera ringan. Selain bencana alam juga terjadi cedera yang dialami mahasiswa akibat cedera aktifitas olahraga bola basket dan bola kaki sekitar 24,2\% dan cedera akibat terjatuh di sekolah sekitar 28,6\%. Cedera pada siswa di lingkungan sekolah umumnya terjadi pada sistem muskuloskeletal yaitu tendon, otot, ligamen, kulit dan tulang. Kecelakaan pada sistem muskuloskeletal harus ditangani dengan cepat dan tepat. Tidak banyak penanganan yang bisa dilakukan oleh pihak sekolah dan langsung membawa mahasiswa/i yang cedera ke rumah sakit terdekat. Jika tidak ditangani dengan cepat akan menimbulkan cedera yang semakin parah dan dapat memicu terjadinya pendarahan. Dampak lain yang terjadi dapat 
mengakibatkan kelainan bentuk tulang atau kecacatan bahkan kematian. Untuk mencegah terjadinya cedera pada sistem muskuloskeletal dibutuhkan pertolongan balut bidai melalui pendidikan kesehatan/pelatihan (Warouw et al., 2018).

Pendidikan kesehatan/pelatihan merupakan usaha atau kegiatan untuk membantu individu, kelompok, dan masyarakat dalam meningkatkan kemampuan baik keterampilan, sikap, maupun keterampilan untuk mencapai hidup sehat secara optimal, bahkan dengan mewajibkan semua mahasiswa/i mendapatkan pendidikan pertolongan pertama di perguruan tinggi, maka kita dapat memastikan bahwa generasi yang akan datang, tiap orang di tempat kecelakaan atau pada penyakit akut akan lebih sanggup menyelamatkan nyawa dan ekstremitas yang cedera sampai tiba bantuan yang profesional (Listiana et al., 2019).

Balut bidai merupakan tindakan memfiksasi atau mengimobilisasi bagian tubuh yang mengalami cedera yang menggunakan benda yang bersifat kaku maupun fleksibel sebagai fiksator/imobilisasi (Rahmawati, 2019). Kecelakaan merupakan kejadian yang tidak bisa diprediksi bahkan banyak kejadian kecelakaan terjadi di sekitar kita. Di kalangan masyarakat bahkan di kalangan mahasiswa/i yang merupakan kawasan yang banyak orang, tetapi orang di sekitar kejadian tidak tahu harus berbuat pertolongan seperti apa sehingga terkadang hanya dibiarkan begitu saja. Jadi peneliti tertarik memberikan pendidikan kesehatan untuk menambah keterampilan dan keberanian dalam melakukan pertolongan. Pertolongan balut bidai dapat dilakukan oleh semua orang awam yang terlatih. Salah satu orang awam yang telatih di perguruan tinggi adalah mahasiswa/i yang telah mendapatkan pendidikan dasar kegawatdaruratan (Suswitha \& Arindari, 2020).

Hasil penelitian sebelumnya didapatkan hasil pengumpulan data setelah dilakukan pelatihan balut bidai. Hasil menunjukkan terjadi peningkatan keterampilan siswa dapat dilihat sebelum pelatihan $10,0 \%$ keterampilan baik menjadi $53,3 \%$ dan penurunan keterampilan yang kurang dari $66,7 \%$ menjadi $10,0 \%$. Selanjutnya, didapatkan hasil penelitian berdasarkan Uji Wilcoxon Signed Rank Test didapatkan keterampilan sebelum perlakuan dan sesudah perlakukan sebesar -4,735 dengan nilai Asymp. Sig $(\mathrm{p})=0,000$. Karena nilai pvalue $=0,000<0,05$ dengan demikian dapat disimpulkan bahwa ada pengaruh pelatihan balut bidai terhadap keterampilan Siswa/i Palang Merah Remaja (PMR) Di SMA N 4 Kota Bengkulu. Peningkatan keterampilan siswa Palang Merah Remaja (PMR) menunjukkan bahwa pelatihan yang diberikan sangat bermanfaat untuk menambah keterampilan mereka dalam melakukan balut bidai. Peningkatan keterampilan ini sesungguhnya tidak lepas dari pemberian pelatihan (Listiana et al., 2019).

Oleh karena itu diperlukan pelatihan balut bidai yang tidak hanya dilakukan pada siswa/i SMA saja, tetapi juga perlu dilakukan pada tingkatan yang lebih tinggi yaitu mahasiswa/i di perguruan tinggi. Sehingga peneliti merasa penting untuk melakukan penelitian pengaruh pelatihan balut bidai terhadap keterampilan pada mahasiswa/i di perguruan tinggi. Penelitian sebelumnya hanya melibatkan jumlah sampel penelitian yang lebih sedikit dan berfokus pada siswa/i anggota Palang Merah Remaja (PMR) di tingkat SMA saja dengan menggunakan metode modul dan video saja, tetapi pada penelitian ini peneliti melibatkan jumlah sampel penelitian yang lebih banyak yaitu seluruh mahasiswa/i keperawatan di STIKES Tri Mandiri Sakti Bengkulu. Keterampilan balut bidai pada mahasiswa/i di perguruan tinggi tidak hanya menggunakan metode dengan modul dan video pembelajaran saja tetapi juga melakukan praktek secara langsung (simulasi). Metode dengan praktek menerapkan dan 
menyesuaikan teori dengan kondisi yang sesungguhnya, sehingga diharapkan dengan penambahan metode praktik secara langsung (simulasi) dapat lebih meningkatkan keterampilan pada mahasiswa/i tentang balut bidai. Video pembelajaran balut bidai pada penelitian ini dibuat sendiri oleh peneliti untuk menjaga originalitas penelitian.

\section{METODE PENELITIAN}

Penelitian ini dilakukan pada bulan Agustus-September 2020 di STIKES Tri Mandiri Sakti Bengkulu. Penelitian ini merupakan penelitian kuantitatif dengan menggunakan penelitian pre eksperimental dengan rancangan one group pre-test and post-test design. Populasi dalam penelitian ini yaitu mahasiswa/i keperawatan semester II dan IV di STIKES Tri Mandiri Sakti Bengkulu.

Teknik pengambilan sampel pada penelitian ini adalah total sampling. Total sampling adalah teknik pengambilan sampel dimana jumlah sampel sama dengan populasi, berjumlah 126 orang. Dari 126 mahasiswa/i keperawatan semester II dan IV dipilih berdasarkan kriteria. Dengan kriteria sampel terdiri dari: a) Kriteria inklusi : mahasiswa/i keperawatan semester II dan IV, belum pernah mendapatkan pelatihan balut bidai, bersedia menjadi responden, tidak berhalangan hadir saat dilakukan penelitian, tidak demam, tidak batuk dan pilek, tidak berpergian ke luar kota selama 14 hari, dan tidak kontak dengan penderita Covid-19, b) Kriteria ekslusi: tidak bersedia menjadi responden, tidak mengikuti penelitian sampai selesai, demam, batuk, dan pilek, berpergian ke luar kota selama 14 hari, dan kontak dengan penderita Covid-19.

Teknik pengumpulan data yang digunakan dalam penelitian ini adalah dengan menggunakan data primer. Data awal yang dikumpulkan dengan melakukan pengisian kuesioner dan lembar observasi, untuk mendapatkan tingkat keterampilan balut bidai sebelum diberikan materi balut bidai dan sebelum diberikan pelatihan balut bidai. Selanjutnya responden dibagikan modul tentang materi balut bidai serta video tentang balut bidai, kemudian diberikan pelatihan balut bidai sehari 2 jam selama 2 kali pertemuan yang disampaikan oleh narasumber pelatihan. Sesudah pelatihan data akhir diambil dengan kuesioner dan lembar observasi post test yang sudah disediakan.

Sebelum penelitian dilakukan peneliti mengajukan Etical Clearence ke instansi yang sudah memperoleh izin untuk melaksanakan proses tersebut yaitu RSUD dr. M. Yunus Bengkulu. Peneliti sangat memperhatikan scientific attitude serta menggunakan prinsip etika dalam penelitian ini. Intervensi dalam penelitian ini tidak memiliki resiko yang dapat merugikan atau membahayakan responden, namun peneliti tetap memperhatikan aspek etis dan humanis, sehingga menjunjung tinggi harkat martabat kemanusiaan.

\section{HASIL PENELITIAN} Analisis Univariat

Tabel. 1

Distribusi Frekuensi Berdasarkan Jenis Kelamin

\begin{tabular}{|c|c|c|c|}
\hline No. & Jenis Kelamin & Jumlah & Persentase $(\%)$ \\
\hline 1 & Perempuan & 107 & 85 \\
\hline 2 & Laki-laki & 19 & 15 \\
\hline & Total & 126 & 100 \\
\hline
\end{tabular}


Berdasarkan tabel 1 diketahui bahwa sebagian besar responden adalah perempuan yaitu sebanyak 107 orang (85\%).

Tabel. 2

Distribusi Frekuensi Keterampilan

Sebelum Perlakuan

\begin{tabular}{clcc}
\hline No. & \multicolumn{1}{c}{ Tingkat Keterampilan } & Frekuensi & Persentase $(\%)$ \\
\hline 1 & Baik & 12 & 9,5 \\
2 & Cukup & 35 & 27,8 \\
3 & Kurang & 79 & 62,7 \\
\hline & Total & 126 & 100 \\
\hline
\end{tabular}

Berdasarkan tabel 2 diketahui bahwa sebagian besar responden memiliki tingkat keterampilan kurang yaitu sebanyak $79(62,7 \%)$ responden.

Tabel. 3

Distribusi Frekuensi Keterampilan Sesudah Perlakuan

\begin{tabular}{clcc}
\hline No. & \multicolumn{1}{c}{ Tingkat Keterampilan } & Frekuensi & Persentase (\%) \\
\hline 1 & Baik & 77 & 61.1 \\
2 & Cukup & 29 & 23,0 \\
3 & Kurang & 20 & 15,9 \\
\hline \multicolumn{2}{l}{ Total } & 126 & 100 \\
\hline
\end{tabular}

Berdaesarkan tabel 3 diketahui bahwa sebagian besar responden memiliki tingkat keterampilan baik yaitu sebanyak 77 orang $(61,1 \%)$ responden.

\section{Analisis Bivariat}

Tabel. 4

Uji Wilcoxon Sign Rank Test

\begin{tabular}{llccccc}
\hline & & $\mathrm{N}$ & Mean Rank & Sum of Ranks & $\mathrm{Z}$ & $\mathrm{P}$ \\
\hline Keterampilan & $\begin{array}{l}\text { Negative } \\
\text { Sesudah- }\end{array}$ & $12^{\mathrm{d}}$ & 11.83 & 142.00 & & \\
$\begin{array}{l}\text { Reterampilan } \\
\text { Sebelum }\end{array}$ & & & & & & \\
\cline { 2 - 7 } & $\begin{array}{l}\text { Positive } \\
\text { Ranks }\end{array}$ & $110^{\mathrm{e}}$ & 66.92 & 7361.00 & -9.241 & .000 \\
\cline { 2 - 7 } & Ties & $4^{\mathrm{f}}$ & & & & \\
\cline { 2 - 7 } & Total & 126 & & & & \\
\hline
\end{tabular}

Berdasarkan tabel 4 menunjukkan bahwa terdapat pengaruh yang signifikan dimana nilai $\mathrm{P}=0,000<0,05$ berarti terdapat perbedaan keterampilan balut bidai pada mahasiswa/i sebelum dan sesudah pelatihan. Artinya, ada pengaruh pelatihan balut bidai terhadap keterampilan mahasiswa/i di STIKES Tri Mandiri Sakti Bengkulu.

\section{PEMBAHASAN}

Berdasarkan tabel 2 menunjukkan bahwa dari 126 orang sebagian besar responden memiliki tingkat keterampilan yang kurang sebelum dilakukan pelatihan balut bidai di STIKES Tri Mandiri Sakti Bengkulu. Responden dengan tingkat keterampilan kurang dikarenakan sebagian besar mahasiswa/i belum memiliki pengalaman dan keahlian 
dasar dalam melakukan balut bidai. Responden dengan tingkat keterampilan cukup sebanyak 35 orang dikarenakan belum memiliki keahlian dasar dalam melakukan balut bidai sebelumnya, sedangkan responden dengan tingkat keterampilan baik terdapat 12 orang yang terdiri dari: 8 orang dengan tingkat keterampilan baik dikarenakan mahasiswa/i tersebut sudah memiliki keahlian dasar teknik balut bidai sebelumnya dan pernah ikut lomba PMR (Palang Merah Remaja) tentang balut bidai sewaktu duduk dibangku Sekolah Menengah Atas (SMA) dan 4 orang tingkat keterampilan baik dikarenakan mahasiswa/i tersebut merupakan anggota ekstrakurikuler Perawat Siaga Bencana (Perwagana) di STIKES Tri Mandiri Sakti Bengkulu sehingga mahasiswa/i tersebut lebih terampil saat mempraktekan balut bidai.

Balut bidai merupakan tindakan memfiksasi atau mengimobilisasi bagian tubuh yang mengalami cedera yang menggunakan benda yang bersifat kaku maupun fleksibel sebagai fiksator/imobilisasi (Rahmawati, 2019). Kecelakaan merupakan kejadian yang tidak bisa diprediksi bahkan banyak kejadian kecelakaan terjadi di sekitar kita, dikalangan masyarakat bahkan dikalangan mahasiswa/i yang merupakan kawasan yang banyak orang, tetapi orang di sekitar kejadian tidak tahu harus berbuat pertolongan seperti apa sehingga terkadang hanya dibiarkan begitu saja sehingga peneliti tertarik memberikan pendidikan kesehatan untuk menambah keterampilan dan keberanian dalam melakukan pertolongan. Pertolongan balut bidai dapat dilakukan oleh semua orang awam yang terlatih. Salah satu orang awam yang telatih di Perguruan Tinggi adalah mahasiswa/i yang telah mendapatkan pendidikan dasar kegawatdaruratan (Suswitha \& Arindari, 2020).

Berdasarkan tabel 3 menunjukkan hasil penelitian diketahui bahwa dari 126 orang terdapat 77 orang $(61,1 \%)$ tingkat keterampilan baik. Hal ini dikarenakan responden memiliki semangat (motivasi diri) yang tinggi dalam mengikuti pelatihan balut bidai, 29 orang $(23,0 \%)$ tingkat keterampilan cukup dikarenakan mahasiswa/i kurang berpartisipasi aktif dalam kegiatan pelatihan yang diberikan, 20 orang $(15,9 \%)$ tingkat keterampilan kurang setelah dilakukan pelatihan balut bidai. Hal tersebut dikarenakan responden kurang bersemangat (motivasi diri yang rendah) dan kurangnya partisipasi dalam mengikuti pelatihan balut bidai.

Hasil penelitian di atas sejalan dengan teori yang menyatakan bahwa motivasi merupakan suatu keinginan dalam diri seseorang untuk melakukan berbagai tindakan, motivasi inilah yang mendorong seseorang bisa melakukan tindakan sesuai dengan prosedur yang sudah diajarkan. Keahlian merupakan kemampuan yang dimiliki seseorang akan membuat terampil dalam melakukan keterampilan tertentu (Listiana et al., 2019). Hal tersebut dapat menyebabkan terjadi peningkatan keterampilan antara sebelum dan sesudah dilakukan pelatihan balut bidai. Keterampilan mahasiswa/i lebih meningkat dilihat melalui motivasi dan partisipasi dalam mengikuti pelatihan balut bidai, rasa ingin tahu dan niat belajar yang ditunjukkan mahasiswa/i melalui kegiatan simulasi dengan mempraktekan balut bidai secara langsung. Mahasiswa/i mengikuti simulasi pada kasus dengan fraktur (patah tulang) pada bagian ekstremitas, dalam proses ini sebagian besar mahasiswa/i melakukan simulasi dengan penilaian yang baik dan melakukan sesuai dengan materi yang telah mereka dapatkan sebelumnya selama pelatihan.

Hasil penelitian di atas juga didukung oleh teori keterampilan merupakan aplikasi dari keterampilan sehingga tingkat keterampilan seseorang berkaitan dengan tingkat keterampilan (Listiana et al., 2019). Peningkatan keterampilan responden dalam penelitian ini disebabkan karena responden memiliki semangat (motivasi diri yang 
tinggi), keahlian dasar, dan rasa ingin tahu terhadap materi balut bidai baik melalui video dan simulasi (Mulyadi \& Katuuk, 2017).

Hasil penelitian ini sejalan dengan penelitian sebelumnya didapatkan hasil pengumpulan data setelah dilakukan pelatihan balut bidai hasil menunjukkan terjadi peningkatan keterampilan siswa dapat dilihat sebelum pelatihan 10,0\% keterampilan baik menjadi 53,3\% dan penurunan keterampilan yang kurang dari $66,7 \%$ menjadi 10,0\% (Listiana et al., 2019). Menurut penelitian sebelumnya tentang keterampilan kader posyandu dalam pengukuran antropometri sebelum dan sesudah pelatihan di Kelurahan Cilandak Barat Jakarta Selatan, didapatkan bahwa peningkatan rata-rata skor keterampilan dari 26,59 \pm 3,796 menjadi 39,00 $\pm 3,185$. Hal ini menunjukkan terjadi peningkatan skor keterampilan sebelum dan sesudah pelatihan sebesar 12,41. Analisis statistik dengan paired t-test menunjukkan bahwa peningkatan tersebut signifikan dengan $P$ value 0,001. Didapatkan hasil setelah diberikan pelatihan dalam kelompokkelompok kecil, terjadi peningkatan yang signifikan untuk skor keterampilan. Peningkatan keterampilan tidak lepas dari peningkatan keterampilan. Selain itu, metode pelatihan yang disampaikan cukup sesuai, yakni dalam kelompok-kelompok kecil yang terdiri dari 2-3 orang dengan bimbingan instruktur. Hal inilah yang menyebabkan informasi yang diterima lebih banyak diserap dan retensinya mampu meningkatkan skor keterampilan (Fitriani \& Purwaningtyas, 2020).

Peneliti menyimpulkan bahwa adanya peningkatan keterampilan balut bidai sesungguhnya tidak lepas dari pemberian pelatihan balut bidai. Pelatihan diberikan dengan cara melakukan praktek secara langsung (simulasi) dilengkapai dengan alat peraga. Namun sebelumnya responden diberikan kesempatan untuk melihat video pembelajaran balut bidai, kemudian dicontohkan oleh narasumber pelatihan dan responden mencoba mempraktikan secara mandiri. Metode dengan praktik menerapkan dan menyesuaikan teori dengan kondisi yang sesungguhnya, sehingga dengan pelatihan yang dilakukan tingkat keterampilan menunjukkan adanya perubahan sesudah diberikan pelatihan balut bidai.

Berdasarkan tabel 4 didapatkan ada pengaruh keterampilan sebelum perlakuan dan sesudah perlakukan pelatihan balut bidai terhadap keterampilan mahasiswa/i keperawatan di STIKES Tri Mandiri Sakti Bengkulu.

Peningkatan keterampilan mahasiswa/i keperawatan menunjukkan bahwa pelatihan yang diberikan sangat bermanfaat untuk menambah keterampilan mereka dalam melakukan balut bidai. Peningkatan keterampilan ini sesungguhnya tidak lepas dari pemberian pelatihan. Pelatihan diberikan dengan cara melakukan praktik langsung dengan menggunakan alat peraga. Namun sebelumnya responden diberikan kesempatan untuk melihat video balut bidai, kemudian dicontohkan oleh narasumber dan mencoba mempraktikan secara mandiri. Metode dengan praktik menerapkan dan menyesuaikan teori dengan kondisi yang sesungguhnya. Sehingga dengan pelatihan yang telah diberikan tingkat keterampilan menunjukkan adanya perubahan sesudah diberikan pelatihan.

Keterampilan merupakan aplikasi dari keterampilan sehingga tingkat keterampilan seseorang berkaitan dengan tingkat keterampilan, dan keterampilan dipengaruhi oleh tingkat pendidikan, umur, pengalaman, motivasi, dan keahlian (Warouw et al., 2018).

Hasil penelitian ini sejalan dengan hasil penelitian sebelumnya bahwa ada perbedaan keterampilan kader posyandu dalam pengukuran antropometri sebelum dan sesudah pelatihan di Kelurahan Cilandak Barat Jakarta Selatan. Dari hasil uji statistik diperoleh nilai $\mathrm{p}=0,001(\mathrm{p}<0,05)$ (Fitriani \& Purwaningtyas, 2020). 
Dari hasil penelitian ini menunjukan ada pengaruh pelatihan balut bidai terhadap keterampilan pada mahasiswa/i keperawatan STIKES Tri Mandiri Sakti Bengkulu. Oleh karena itu diharapkan kepada STIKES Tri Mandiri Sakti Bengkulu agar mampu bekerjasama dengan PMI (Palang Merah Indonesia), Puskesmas, ataupun pihak yang berwenang tentang penanganan pertama cedera sehingga dapat membantu mahasiswa/i dalam melakukan upaya penanganan terhadap cedera. Diharapkan juga pihak STIKES Tri Mandiri Sakti Bengkulu untuk melakukan pelatihan secara rutin dan berkelanjutan agar meningkatkan keterampilan dan keterampilan mahasiswa/i tentang pentingnya penanganan pertama, sehingga mereka bisa menerapkan keterampilannya di lingkungan Perguruan Tinggi maupun di masyarakat.

\section{SIMPULAN}

Ada pengaruh pelatihan balut bidai terhadap keterampilan pada mahasiswa/i keperawatan di STIKES Tri Mandiri Sakti Bengkulu.

\section{SARAN}

Diharapkan kepada institusi pendidikan keperawatan agar pelatihan balut bidai dapat dijadikan sebagai sumber informasi tambahan mengenai peran dan fungsi perawat di perguruan tinggi, yang bermanfaat dalam pembelajaran mahasiswa/i keperawatan agar mengetahui dan memahami peran dan fungsinya, serta dapat mengaplikasikannya dalam kehidupan sehari-hari baik di lingkungan Perguruan Tinggi maupun di Masyarakat.

\section{DAFTAR PUSTAKA}

Andri, J., Febriawati, H., Padila, P., Harsismanto, J., \& Susmita, R. (2020). Nyeri pada Pasien Post Op Fraktur Ekstremitas Bawah dengan Pelaksanaan Mobilisasi dan Ambulasi Dini. Journal of Telenursing (JOTING), 2(1), 61-70. https://doi.org/https://doi.org/10.31539/joting.v2i1.1129

Desiartama, D., \& Aryana, A. (2017). Gambaran Karakteristik Pasien Fraktur Femur akibat Kecelakaan Lalu Lintas pada Orang Dewasa di Rumah Sakit Umum Pusat Sanglah Denpasar Tahun 2013. E-Jurnal Medika, 6(5), 1-4. https://ojs.unud.ac.id/index.php/eum/article/view/30486

Fitriani, A., \& Purwaningtyas, D. R. (2020). Peningkatan Keterampilan dan Keterampilan Kader Posyandu dalam Pengukuran Antropometri di Kelurahan Cilandak Barat Jakarta Selatan. Jurnal Solma, 9(2), 367-378. DOI: 10.22236/solma.v9i2.4087

Listiana, D., Effendi, E., \& Oktarina, A. R. (2019). Pengaruh Pelatihan Balut Bidai terhadap Keterampilan dan Keterampilan pada anggota Palang Merah Remaja (PMR) di SMA N 4 Bengkulu. CHMK Nursing Scientific Journal, 3 (2), 145-156. http://cyber-chmk.net/ojs/index.php/ners/article/view/580

Mulyadi, M., \& Katuuk, M. E. (2017). Pengaruh Simulasi Tindakan Resusitasi Jantung Paru (RJP) terhadap Tingkat Motivasi Siswa Menolong Korban Henti Jantung di SMA Negeri 9 Binsus Manado. Jurnal Keperawatan Universitas Sam Ratulangi, 5(1), 1-8. https://ejournal.unsrat.ac.id/index.php/jkp/article/view/25100

Najihah, N., \& Ramli, R. (2019). Pendidikan Kesehatan Pertolongan Pertama pada Kecelakaan Meningkatkan Keterampilan Anggota PMR tentang Penanganan Fraktur. Jurnal Penelitian Kesehatan Suara Forikes, 10 (2), 151-154. http://forikes-ejournal.com/index.php/SF 
Rahmawati, R. (2018). Pengaruh Pembidaian terhadap Penurunan Skala Nyeri pada Pasien Praktur tertutup di Ruangan IGD RSAM Bukittinggi Tahun 2018. Stikes Perintis

Sumadi, P. L. (2020). Pengaruh Pelatihan Pertolongan Pertama pada Kecelakaan terhadap Keterampilan Penanganan Fraktur pada Anggota PMR Di SMP Negeri 2 Kuta Utara. Jurnal Keperawatan Muhammadiyah, 5(1), 19-23. http://dx.doi.org/10.30651/jkm.v5i1.2874

Suswitha, D., \& Arindari, D. R. (2020). Pengaruh Simulasi First Aid Kegawatdaruratan Kecelakaan terhadap Keterampilan Penanganan Fraktur. Babul Ilmi_Jurnal Ilmiah Multi Science Kesehatan, 12(1), 97-109. http://jurnal.stikes-aisyiyahpalembang.ac.id/index.php/Kep/article/view/369

Warouw, J. A., Kumaat, L. T., \& Pondaag, L. (2018). Pengaruh Pendidikan Kesehatan dan Simulasi terhadap Keterampilan tentang Balut Bidai Pertolongan Pertama Fraktur Tulang Panjang pada Siswa Kelas X SMK Negeri 6 Manado. ejournal

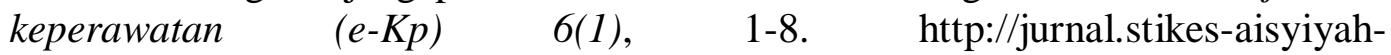
palembang.ac.id/index.php/Kep/article/view/369 